\title{
Doing Public Theology in African Christianity: A Reflection on Communiques by Churches in Ghana
}

\author{
Kwabena Opuni-Frimpong ${ }^{1}$ \\ 1 Department of Religious Studies - Kwame Nkrumah University of Science and Technology, Kumasi - Ghana.
}

\begin{abstract}
Faith in public life can be associated with Christianity in Ghana from the days of the early Western missionaries. Christian faith perspectives on matters of public concerns however, assumed a wider scope with the practice of regular issuance of communiques to governments and the people of Ghana by the churches. Christian ministry is expected to be holistic. A holistic approach in Christian ministry is considered to lead to the holistic development of the nation for the common good and the glory of God. Church leaders subsequently, bring their faith perspectives to matters of public concerns as a ministerial mandate to be in pilgrimage with the people. The study is a reflection on how the churches' communiques are done and the factors that make the communiques theological in the public space. It further seeks to identify the contribution of the construction of communiques to public theology in Christianity in Ghana. The study as qualitative, examines both available primary and secondary sources. Copies of communiques of some selected churches, ecumenical bodies and joint communiques by ecumenical bodies are examined to appreciate insights of communiques by the churches. The study seeks to make a contribution to the theological construction of public theologies in Ghana and African Christianity.
\end{abstract}

Correspondence:

Kwabena Opuni-Frimpong Email: opuni@hotmail.com

Publication History Received 20th September, 2021, Accepted 5th November, 2021, Published online 15th November, 2021.

\section{KEYWORDS}

Public Theology, African Christianity, Communique, Common Good

\section{INTRODUCTION}

Bringing faith perspectives on public issues has remained a common practice by the churches in Ghana. ${ }^{1}$ The churches over the years have demonstrated participation in public matters through the issuance of pastoral Letters, writing of official letters to Heads of States, various churches newspapers e.g., Christian Messenger by the Presbyterian Church of Ghana, the Methodist Times by the Methodist Church Ghana and the Standard by the Catholic Church. A major pattern of bringing faith perspectives into the public sphere however, has remained the issuance of communiques by the churches.

The Presbyterian Church of Ghana (PCG) during its 65 ${ }^{\text {th }}$ Synod at Sunyani in 1994 took a decision to send communiques to the Governments and people of Ghana at the end of every Synod meeting. Synod, which is now termed General Assembly by the PCG, decided that a 'Communique be sent to the Head of State anytime Synod met. This is to replace the traditional message of greetings to the Head of State.'

\footnotetext{
Noel Smith. The Presbytery Church of Ghana 1835-1960 (Accra: Ghana Universities Press 1966).

2 Presbyterian Church of Ghana Synod Decisions of 65 ${ }^{\text {th }}$ Synod held at Sunyani on August 20-24, 1994.
} 
The rationale was that until 1994, a letter containing a message of greetings was sent to the Head of State at the end of Synod meetings. The PCG was however, seeking a bigger space to influence public issues and therefore considered that the issuance of communiques to the people and government of Ghana would facilitate the commitment of the Church to influence social change. ${ }^{3}$ Communique, which is considered to be an open memorandum to the press which is meant for the general public and the government was intended to effectively bring the issues to the public domain for influence and action.

The view of the PCG was that, 'to partner the Government in governance, a communique would make more impact than a mere message since a communique would call Government's attention to burning issues that needed attention in the country. ${ }^{4}$ Consequently, Synod decided to replace a message of greetings with a communique anytime it met. The rationale of other churches in the issuance of communiques have similar reasons to that of the PCG. The issuance of communiques by the ecumenical bodies like the Christian Council of Ghana however, takes its practice from their various international ecumenical parent bodies like the World Council of Churches and the All African Conference of Churches.

The decision to have a wider spread and influence in the public domain with Christian faith values and perspectives has remained with individual churches and ecumenical bodies in Ghana. The practice is influenced by the significant Christian presence in Ghana. James Anquandah has noted that, 'the annals of Ghanaian history show that Christians who are the majority in the nation's population, have over the decades been directly or indirectly connected with the vicissitudes of the nation whether in affairs of governance, systems of education, health, agriculture, trade, industry, etc. The bulk of state or government officials and personnel have been, and are, Christians, whether it be in democratic political regimes or military regimes. ${ }^{5}$

Ghana is generally a very religious nation. The country however, is considered as a secular nation according to Article 56 of the 1992 constitution without allowing any particular religion to dominate matters of governance. The consideration of Ghana as a secular state has influenced the position of some concerns that the church must focus on matters of evangelism and spirituality and leave secular and social matters to governments and political leaders.

The separation between the church and the state however, has not been a welcoming position for the churches. It is actually strange to the churches for some people to view the church to limit itself to matters considered only as spiritual and distance itself from public issues in Ghana. According to John Stott, 'it is exceeding strange that any followers of Jesus Christ should ever have a need to ask whether social involvement was their concern, and that controversy should have blown up over the relationship between evangelism and social responsibility. ${ }^{\prime}$

It is evident in the public ministry of Jesus that he both went about teaching and preaching which may be considered as evangelism. 'And Jesus went about all Galilee, teaching in their synagogues, and preaching the gospel of the kingdom,' (Matt 4:23, 9:35). He also went about doing good and healing the sick as social responsibility and concern. 'How God anointed Jesus of Nazareth with the Holy Ghost and with power: who went about doing good, and healing all that were oppressed of the devil; for God was with him' (Acts 10:38). Jesus' public ministry example is the paradigm for the churches.

Stott has therefore opined that, 'evangelism and social concern have been intimately related to one another throughout the history of the church. Christian people have often engaged in both activities quite unselfconsciously, without feeling any need to define what they were doing or why. ${ }^{77}$ Christian social responsibility presupposes that the church must be socially responsible.

The role of religion in general should be one that gives hope. Churches must give hope. Christian hope however, must be beneficial to both people in the church as well as those who are outside the church who may be considered to be the public church. Accordingly, Olav Fykse Tveit, ${ }^{8}$ has argued that, "if it is not a hope for all, it is not a real hope, and it is not a Christian hope. A necessary condition for hope is that it expresses

\footnotetext{
Joseph Mante, and D. Aboagye-Dankwa, Presbyterian Church of Ghana, Synod Decisions and the Rationale behind the decisions (1975-200), (Accra: Adwinsa Publications, 2014), 110-111.

4 Presbyterian Church of Ghana Synod Decisions of 65th Synod held at Sunyani on August 20-24, 1994.

5 James Anquandah, Agenda Extraordinaire: 80 years of the Christian Council of Ghana 1929-2009. (Accra: Asempa Publishers 2009), 113.

6 John Stott. Issues Facing Christianity Today. (London: Marshall Pickering 2006), 2.

7 Stott. Issues Facing Christianity Today, 2.

8 Olav Fykse Tveit was the General Secretary of the World Council of Churches 2010-2020.
} 
itself in love for others, whoever and wherever they are. ${ }^{9}$ Churches get themselves involved in the public affairs of the nation to offer hope.

The voice of the church in matters that affect the nation has been raised and heard in reflections on matters of public interest and concerns. Tveit again has noted that religions orient the lives and important decisions of many families and communities on a strong base of values. With their holistic world views, religions continue to challenge the development of economic and political sub-systems that dominate societies and undermine and fragment life in a community. ${ }^{10}$

Faith in public life must be directed by the Christian faith, doctrines and the Christian witness. There is the tendency to reduce the Christian faith perspectives on public concerns by national and global public policy goals. Christian faith in the public space must remain confident and trust in God, in the content of Christian doctrine, in the teaching of Christian traditions, in a commitment to serve and share, in embodying a community of faith and practice, in common witness in words and deeds. ${ }^{11}$

This study therefore seeks to examine the principles that guide the making of communiques by the churches and its contribution to the theological construction of public theologies in Ghana and African Christianity. A reflection on the preparation of these communiques by the churches is intended to bring out insights into the preparation process. The insights definitely will inform future preparation and studies of communiques and subsequently points out the contribution of issuance of communiques to public theology in African Christianity.

\section{METHODOLOGY}

The study is purely qualitative and thrives on information from library research. It examines both primary and secondary materials on the subject. Much attention is paid to some selected communiques by the Presbyterian Church of Ghana, Christian Council of Ghana and Joint communiques issued by the Christian Council of Ghana with the Ghana Catholic Bishop Conference and the Ghana Pentecostal and Charismatic Council and communiques by the All African Conference of Churches. The selected communiques will be examined to appreciate insights of communiques by the churches.

\section{Public Theology}

Public theology is theology that is public. It is theology in the public sphere or the Christian gospel in public life. Faith in public life has been noticed throughout church history. The concept 'public theology' or 'public church' was however, introduced into theological circles by Marty Martin in the 1970s. ${ }^{12}$ Public theology is the response to the questions about the public role of the Church. ${ }^{13}$ It has been considered as the public witness of the church by Karel August. ${ }^{14}$ Public theology is the effort of the people of God to bring Christian understanding and perspectives on matters of public concern with the intention to contribute to social change and transformation for the common good of the people and the glory of God.

The engagement of the church and public concerns is expected to be done by presenting the Christian positions in a way that can be publicly understood and considered. Public theology though functions within the public space, is expected to remain theological at all times. It avoids the tendency of being reduced to other social sciences and development theories. ${ }^{15}$ It has its roots always in Scripture, traditions of the church, led by the Holy Spirit and remains as a Christian witness. It eventually gives glory to God and contributes to the common good.

Public theology in Ghana has been done mainly through the issuance of official statements and communiques by the Christian communities. Church communiques in Ghana are usually issued by individual

\footnotetext{
9 Olav Fykse Tveit. The Role of Religion in Sustainable Development and Peace. Berlin World Council of Churches. February 17-18, 2016.

10 Tveit, The Role of Religion in Sustainable Development and Peace.

11 Tveit, The Role of Religion in Sustainable Development and Peace.

12 Sebastian, Kim. Theology in the Public Sphere: Public Theology as a Catalyst for Open Debate. (London: SCM Press 2011).

13 August T. Karel. The Quest for Being Public Church, The South African Challenge to the Moravian Church in Context 17372004. (Bellville: The Print-Man 2009), 213.

14 Karel. The Quest for Being Public Church, The South African Challenge to the Moravian Church in Context 1737-2004. 213.

15 Tveit, The Role of Religion in Sustainable Development and Peace.
} 
churches, like the PCG, ${ }^{16}$ Ecumenical Bodies such as the Christian Council of Ghana ${ }^{17}$ and Joint Ecumenical Bodies such as the Christian Council of Ghana and the Ghana Catholic Bishops Conference. ${ }^{18}$

The issues that have attracted the attention of faith perspectives in public life include education, health, economic prosperity, employment, good governance, human rights, credible elections and interfaith harmony. Public theology is a demonstration of the holistic ministry of the church. Emmanuel Asante has opined that, 'a holistic definition of ministry, however, must include aspects of human well-being, or what the economists call welfare, in areas, such as health, food, education, housing, employment, the environment, religious and cultural values and sustainability of each of these. ${ }^{19}$

\section{What Is The 'Public' Of Public Theology?}

The question that must be answered is what is the public of public theology? A reflection on the destinations of the communiques provides responses to the considered public sphere of public theology. The communiques provide its recipients in the preamble as to the people and government of Ghana. The communiques are usually directed to the public through the media and the key actors of public policy in the country.

\section{The Church and Media}

The media has played a very significant role in the governance system of Ghana. Asante has noted that, 'the media provide and facilitate the flow of information, they constitute an important component of the political process in democracies. ${ }^{20}$ Through the instrumentality of the media, one is able to get information about any aspect and topic of life, including religion, governance, public policies etc. in Ghana and beyond. ${ }^{21}$ Church leaders have pursued media engagements through press releases, communiques, panel discussions and documentaries.

The various media patterns provide the space for faith perspectives on public concerns. The communiques are usually discussed on radio, television, the newspapers and on social media. The church leaders are called upon to provide insights into the opinions expressed. The issues often provide platforms for engagements and dialogue in the media space. ${ }^{22}$ The contemporary social media platforms have widened the scope of discussion and engagements. The communiques find their way on YouTube, WhatsApp platforms, Facebook, and the websites of the churches. Ordinary people are given space to write their individual comments on the issues that the churches raise in the public space.

The media influences the perception, lens, and impressions that people use to measure, assess, and interpret public life and actions. Public opinion 'influences decision making process of both individuals and corporate entities on matters of public policies. ${ }^{23}$ The churches have influenced public opinion on public policy issues through their issuance of communiques.

\section{The Church and Public Policy}

Public policies are the decisions of governments. They include what governments decide to do or not to do with national resources. ${ }^{24}$ The public policy cycle usually involves consultations with Civil Society Organizations and Faith-Based Organizations. The communiques which normally do reflections on public policy issues are presented to the governments which are considered as opinions from the churches. The public policy formulation and implementation platforms further provide public space for the faith and public policy engagements.

${ }^{16}$ Communique issued by the Presbyterian Church of Ghana (PCG) at the end of its $19^{\text {th }}$ General Assembly at Abetifi-Kwahu in the Eastern Region of Ghana from $16^{\text {th }}-22^{\text {nd }}$ August, 2019.

${ }^{17}$ Communique on National Issues by the Christian Council of Ghana adopted at the Joint Heads of Churches and Organizations and Executive Meeting of the Christian Council of Ghana held at its Secretariat on December 17, 2013.

18 Joint Press Statement by the Christian Council of Ghana and the Ghana Catholic Bishops' Conference Issued in Accra on May $18,2016$.

19 Emmanuel Asante. Theology and Society in Context: A theologist's reflections on selected topics. (Accra: SonLife Press 2014), 5.

20 Asante. Theology and Society in Context: A theologist's reflections on selected topics, 88.

${ }^{21}$ Kwabena Opuni-Frimpong. Christian Ministry of Advocacy. (Accra: Sonlife Press 2015), 58.

22 Paul Gifford. Ghana's New Christianity. (Indianapolis: Indiana University Press 2004).

${ }^{23}$ Opuni-Frimpong. Christian Ministry of Advocacy, 76

${ }^{24}$ Opuni-Frimpong. Christian Ministry of Advocacy, 76 
Implementation of public policies has its challenges. According to Joseph Ayee, 'in developing countries of Africa, Asia, and Latin America, public policies often do not get implemented at all, and those which do manage to get through the tortuous process of implementation often look very different from what the framers originally intended. ${ }^{25}$

When public policies are not implemented or not implemented according to the intended outcomes the citizens suffer. The common good becomes threatened. The challenges of lack of proper implementation of public policies have been recognized and considered by the churches and ecumenical bodies. The All African Conference of Churches communique issued in 2016 noted that, 'recognizing the need to make the compassionate voice of Faith Based Organizations (FBOs) and of all morality sing out loud and clear to challenge the voices of hatred, exclusion, chauvinism and extremism. ${ }^{26}$ The idea of the churches challenging the voices of neglect, exclusion and extremism must be as the result of a lack of proper implementation of public policies.

Paying attention to political leaders who are the key administrators of public policies is very crucial for development. Ayee has opined that, 'leadership at all levels has increasingly been singled out as the most important variable that has shaped the various developments and governance outcomes witnessed on the African continent. ${ }^{27}$ Consequently, the blame for development and political failures lies squarely at the feet of self-interested or misguided leaders whose choices, it is believed, have undermined prosperity and stability. At the same time, success is attributed to deft guidance by effective political and bureaucratic leaders.

The role of church leaders in the governance of the nation is duly recognized. According to Aryee, 'leadership is a political process which involves the skills of mobilizing people and resources to achieve a set of shared and negotiated goals. It refers not only to national political leaders but equally to leadership at subnational levels and in all sectors of society - in businesses and business organizations, trade unions, NGO's, professional associations, churches and bureaucracy - and in the relations between them.' ${ }^{28}$ Church leadership is recognized as a key leadership that must make a contribution to national development. The church leaders' perspectives on public matters have become an expectation by the public to the extent that the failure or long delays of the church leader's participation in matters of public concerns are considered as neglect of Christian social responsibility of the faith leaders.

\section{Some Biblical and Theological Basis}

Christian faith in public life takes its foundations from Scripture and theological traditions. According to Gustavo Gutierrez, 'the Bible is the book of the Promise, the Promise made by God to human beings, the efficacious revelation of God's love and self-communication; simultaneously it reveals humankind to itself.' ${ }^{29}$ The Promise, which is at the same time revelation and Good News, is the heart of the Bible. There have been instances that the Churches in Ghana have received suggestions to stay away from politics and governance and restrict their work to matters of faith and spirituality. ${ }^{30}$ The churches have remained in matters of public policy since its inception and therefore have not paid much attention to rescind from matters of governance and politics.

The early missionaries pursued first and foremost spiritual goals. But this does not mean that they were content with the spreading of the Gospel alone. The theological foundations of the Basel Missionaries according to Peter Schweizer for example was on their interpretation of Christian compassion, and also the Zwinglian ethics of ora et labora (pray and work). The theological tradition guided the missionaries from the very outset to create prospects for the economic betterment of the indigenous population. The ambitious missionary programmes, which included the construction of churches, schools, hospitals, agriculture required sound logistics, entrepreneurial skills and financing. ${ }^{31}$

There are several personalities and passages from the Bible that the churches have used to maintain

\footnotetext{
25 Joseph R.A. Aryee, An Anatomy of Public Policy Implementation, (Avebury Brookfield USA 1997), 1

${ }^{26}$ Communique issued by the All African Conference of Churches held at Desmond Tutu Conference Centre Nairobi, Kenya on

November 29-30, 2016.

27 Aryee. Leadership and the Ghanaian State Today: Reflections and Perspectives, vi.

28 Aryee. Leadership and the Ghanaian State Today: Reflections and Perspectives, 1.

${ }_{29}$ Gutierrez Gustavo. A Theology of Liberation. (New York: Orbis Books 1988), 91.

30 J.N. Kudadjie, JN. and R.K. Aboagye- Mensah. Christian Social Ethics (Accra: Asempa Publishers 1992), 28.

31 Peter A. Schweizer Survivors on the Gold Coast. (Accra: Smartline Publishing 2000), 93.
} 
their efforts to bring faith perspectives on governance and policy issues. The Bible, it is considered, has the power to affect individual and social transformation. Stott opines that, 'evangelism is the major instrument of social change. For the gospel changes people, and changed people can change society. ${ }^{32}$

The claim of Jesus on the fulness of life has remained a motivation in public theology. 'The thief does not come except to steal, and to kill, and to destroy. I have come that they may have life, and that they may have it more abundantly' (John 10:10). The fullness of life responds to offering healing to the sick, food to the hungry and dignity to the downtrodden. The church flowing from the example of Christ brings meaning and fullness to the environment within which it serves. The fullness of life is expressed in terms of meeting the basic needs of life that make life meaningful. Poverty, disease, unemployment, civil wars, hunger are considered detriments of life. The church, therefore, contributes to the fullness of life by supporting policies that support social interventions and are pro-poor.

The call for the church to serve as the light of the world continuously demands churches participation in social matters. The world is considered to be in darkness. Christians who have experienced Jesus Christ as the light of the world are required to bring their faith and lifestyles as a demonstration to the society. 'You are the light of the world. A town built on a hill cannot be hidden. Neither do people light a lamp and put it under a bowl. Instead, they put it on its stand, and it gives light to everyone in the house. In the same way, let your light shine before others, that they may see your good deeds and glorify your Father in heaven' (Matt 5:14-16). According to Stott, 'the world is dark, Jesus implied but you (Christians) are to be its light. The world is decaying, but you are to be its salt and hinder its decay. ${ }^{33}$ The world which is considered to be in darkness needs the Church to reflect the light of Christ to make life meaningful. The world must find light in its darkness as a result of the presence and participation of the church in public matters.

The call for the people of God to stand in the gap on behalf of the nation serves as motivation for the churches. Evil can survive when the righteous do nothing. If those who have tasted the love of God will stand up for truth and righteousness, the nations will know the favor of God. In the Book of Ezekiel, the prophet says on behalf of God, 'I looked for anyone to repair the wall and stand in the gap for me on behalf of the land, so I wouldn't have to destroy it. But I couldn't find anyone' (Eze 22:30). Accepting to stand in the gap presents the church as a vessel that God can use to reach out to a wounded society.

The people of God have been called to seek the peace and prosperity of the city for it is in its peace that they will also find their peace and prosperity. 'Also, seek the peace and prosperity of the city to which I have carried you into exile. Pray to the Lord for it, because if it prospers, you too will prosper' (Jer. 29:7). The show of interest and concern is connected to the church's own peace and prosperity. The members of the church are also members of the society. The church cannot look on whiles its members wallow in pain and poverty without a show of support and concern. The churches and their members are active citizens who equally share the pain and blessings of the society. The prosperity of the society brings blessing and betterment of life to the church members. The church consequently, must seek the peace of the nation for in its peace the church and its members will have peace.

Scripture provides the people who are called by the name of God to make special intercessions for the healing of the land. 'If my people, which are called by my name, shall humble themselves, and pray, and seek my face, and turn from their wicked ways; then will I hear from heaven, and will forgive their sin, and will heal their land' (2 Chron 7:14). The world that can be sick of sin, suffering and injustice must have the church with the prophetic voice to confront the world in its sinfulness and also to bring it to God's love, hope and comfort. There is a divine call for the church to make interventions for the nation. Due to their relationship with the lord, he will hear their intercessions.

Prayer is an indispensable part of the Christian life. The Apostle Paul instructed that, 'I urge, then, first of all, that petitions, prayers, intercession and thanksgiving be made for all people - for kings and all those in authority, that we may live peaceful and quiet lives in all godliness and holiness. This is good, and pleases God our Savior, who wants all people to be saved and to come to a knowledge of the truth.' (1 Tim 2:1-4). A call for prayers for national leaders, that they may fulfill their responsibility to maintain conditions of peace, in which the church is free both to worship God and to preach the gospel.

Jesus presented God in the Family/the Lord's prayer as Father in Heaven. In his fatherhood, God has

\footnotetext{
32 Stott. Issues Facing Christianity Today, 7.

33 Stott. Issues Facing Christianity Today, 66.
} 
consistently shown interest in the affairs of humanity by sending messengers of hope to make interventions for deliverance and prosperity. Biblical personalities like Moses, Esther, Amos, Nehemiah and many more keep reminding the church to take preferential interest in the affairs of the needy and the poor. The Fatherhood of God demands that the church must participate in matters of public interest. God is a father who will want the best for his children. He has interest and pleasure in the well-being of his children an example that the church is called upon to emulate.

\section{Historical Perspectives and Examples}

Christian history in Ghana is indicative of the constant involvement of the church in public matters as has been mentioned earlier on. The churches have never ceased to participate in public issues from the missionary era, before, during and after independence. There is visible church growth in Ghana. The growth is seen in the number of Christians in governance and leadership. It is expected that the massive Christian presence will have an impact on the quality of life of the nation..$^{34}$

Western missionaries who worked in different parts of Ghana came primarily to spread the gospel. The Christian understanding of the missionaries, however, indicated that the gospel demands participation in the process towards the well-being of the recipients of the gospel. In the various mission stations, issues of education, health, agriculture, industry and quality of life remained on the agenda of missionaries. While they pursued some of such developmental projects on their own, Debrunner ${ }^{35}$ and Kwamena-Poh ${ }^{36}$ have indicated that they also partnered with the colonial authorities to meet the human needs of the people that they had come to share the gospel.

The participation of the church in the efforts of Ghana towards independence was very phenomenal. The Christian Council of Ghana participated in the discussions towards independence and provided the spiritual and Christian perspectives on the independence efforts. The statement of the Christian Council of Ghana in August 1940 made a significant contribution to the road towards Ghana's independence. Anquandah has noted that, 'the Coussey Committee had just submitted its proposals for preparing the country for self-government. It was in that month that the Christian Council caused quite a stir on the Ghanaian scene by a publication, in several newspapers, of a public statement entitled 'Christianity and Political development'. The statement was signed by fifteen members of the Christian Council Executive Committee including General Secretary Rev J. Bardsley, Rev Christian Baeta, Rev M.B. Taylor and Dr. Eugene Grau, Principal of Trinity College., ${ }^{37}$

The churches played a very significant role in the post-independence of Ghana. The churches engaged the government of the Nkrumah regime on several public policy matters. The Christian Council of Ghana is on record to have sent a series of letters to the Government on several governance and human rights issues. The typical case in point is the introduction of the Preventive Detention Act. The Act allowed the government to hold some citizens in detention for long periods without trial. The Christian Council in a series of letters challenged the Act. ${ }^{38}$ Even though President Nkrumah did not agree with the churches at the time, the law was eventually repelled from the laws of Ghana.

The unique role of the church during the military era in the governance of Ghana was its call to the military to go back to the barracks and return the nation to democratic governance. The Christian Council of Ghana and the Ghana Catholic Bishops Conference issued a joint communique to the Armed Forces Revolutionary Council on June 28, 1979, calling for the discontinuation of the execution of former military Generals during the military takeover of the nation. The communique was jointly signed by Rev C. AwortwiPratt, Chairman of Christian Council of Ghana and Rt. Rev. Dominic Andoh, President of the Catholic Bishops Conference. Similar joint communiques were sent to the PNDC to return the country to constitutional and democratic governance on November 28, 1982.

When the Provisional National Defense Council (PNDC) finally decided to return the county to democratic governance, the ecumenical bodies played a very vital role. It was at this time that the PNDC Government initiated the process to return the country to democratic rule. It therefore set up a constituent

\footnotetext{
34 Anquandah. Agenda Extraordinaire: 80 years of the Christian Council of Ghana 1929-2009, 113.

35 Hans W. Debrunner Hans W. A History of Christianity in Ghana. Accra: Waterville Publishing House 1967

36 M. A. Kwamena-Poh. Vision \& Achievement. Accra: Waterville Publishing House, 2011.

37 Anquandah. Agenda Extraordinaire: 80 years of the Christian Council of Ghana 1929-2009, 113.

38 Anquandah. Agenda Extraordinaire: 80 years of the Christian Council of Ghana 1929-2009, 115
} 
assembly to draft the constitution for the $4^{\text {th }}$ Republic. The Christian Council, the Catholic Bishops Conference and the Ghana Pentecostal Council were the key ecumenical bodies invited to serve on the Constituent Assembly. The draft constitution received approval from the people of Ghana through a referendum and this was followed by the formation of political parties and the presidential and parliamentary elections. ${ }^{39}$

The church has been a key player under the $4^{\text {th }}$ republic on matters of consolidation of democratic governance. The functions include free, fair, and credible elections. Transparency accountability, and corruption have remained at the center stage of the church's involvement in public issues.

\section{The Process Towards the Issuance of Communiques}

The issuance of communiques in Ghana are done by individual churches. The Presbyterian Church of Ghana, for instance, ends its annual General Assembly meetings with the issuance of communiques. ${ }^{40}$ The task of drafting the communiques is assigned to the church's Committee on Church and Society which is under the Department of Ecumenical and Social Relations. The committee presents the draft communique to the plenary session of the Assembly which is reflected upon by the whole General Assembly according to the various items presented. The communique gets accepted and approved by the whole Assembly before the Moderator and the General Assembly Council of the Assembly are tasked to make the communique available to the government and people of Ghana.

The Membership of the Committee of Church and Society of the Presbyterian Church of Ghana which is responsible for drafting communiques for the General Assembly is made of two ministers, one presbyter, one lawyer, one sociologist, one expert in African Traditional Religion/Affairs, one industrialist/business executive, the Editor of Christian Messenger, the Public Relation Officer and the Director - Department of Ecumenical and Social Relations.

The Committee is tasked to, 'study the socio-economic and political climate of the Ghanaian society and make recommendations to the General Assembly for its intervention. Monitor over developments in the country's life especially in areas where moral and spiritual considerations arise and consider what actions the Church may from time to time take to further the highest interest of the people. Present to the General Assembly in session a draft communique for adoption. Study and make recommendations about contextualization of Christianity in the Ghanaian Society. Organize symposia and other programmes on topics of national and international interest and perform any other functions as may be directed by the General Assembly. ${ }^{, 4}$

The Ecumenical bodies which are also into regular issuance of communiques do so individually and jointly. The Christian Council of Ghana issues communiques at the end of their annual General Meetings and quarterly Executive Committee meetings. ${ }^{42}$ The General Secretary and the Secretariat present the draft communique to the Assembly and the Executive Committee for reflection. The reflection is done by all members of the Executive Committee before its acceptance and approval. Approval is given after various corrections and additions are done. The task of making the communique available to the public is the responsibility of the Chairman and General Secretary of the Council after they append their signatures to the communiques.

The Christian Council of Ghana and other Ecumenical Bodies such as the Ghana Catholic Bishops Conference and the Ghana Pentecostal and Charismatic Churches have entered into various Memorandum of Understandings. The partnerships bring them into annual meetings. The Joint meetings usually end with church services and the issuance of communiques. The Christian Council and the Catholic Bishops relationship that predates the independence of Ghana has constantly issued communiques to Governments and Ghanaians. ${ }^{43}$

The Christian Council of Ghana and the Ghana Pentecostal and Charismatic Council entered into a formal ecumenical relationship through the signing of a Memorandum of Understanding. The ecumenical relationship brings the ecumenical bodies together for annual meetings. The ecumenical meetings which end

\footnotetext{
39 Anquandah. Agenda Extraordinaire: 80 years of the Christian Council of Ghana 1929-2009, 122.

${ }^{40}$ Communique issued by the Presbyterian Church of Ghana (PCG) at the end of its $19^{\text {th }}$ General Assembly at Abetifi-Kwahu in the Eastern Region of Ghana from $16^{\text {th }}-22^{\text {nd }}$ August, 2019.

${ }^{41}$ Presbyterian Church of Ghana, Manual of Order. (Accra: Waterville Publishing House, 2017), 114-115.

42 Communique on National Issues by the Christian Council of Ghana adopted at the Joint Heads of Churches and Organizations and Executive Meeting of the Christian Council of Ghana held at its Secretariat on December 17, 2013.

43 Joint Press Statement by the Christian Council of Ghana and the Ghana Catholic Bishops' Conference Issued in Accra on May $18,2016$.
} 
with church services also engage them in the reflections on national issues. The Joint meeting similarly ends in the issuance of communiques to the nation. ${ }^{44}$

\section{The Christian Leadership Mandate}

The individual churches and ecumenical bodies claim ministerial mandates in the issuance of their communiques. The preambles of the communiques that usually state the date and venue of the meetings also establish the considered mandate of the church and ecumenical leaders. The communiques are issued on the grounds of leadership. The Christian Council of Ghana joint meeting with the Ghana Pentecostal and Charismatic Council claimed that the positions that they hold as church leaders demand that they do reflections on national issues and offer their Christian faith perspectives.

The preamble of the joint communique stated that, "we the members of the Christian Council of Ghana (CCG) and Ghana Pentecostal and Charismatic Council (GPCC) send you our warmest greetings of peace and love. We believe that the joy of the Risen Lord still remains with you and continues to fill you with hope. We have just concluded our first Joint Meeting following our partnership agreement at the Osu Ebenezer Presbyterian Church on Wednesday June 8, 2016. During the time we prayed and discussed issues of both Church and national importance. At the end of our meeting, we deem it appropriate as Christian leaders of our land to bring the following pertinent issues affecting our nation and the church to the attention of our government and our citizens so that we can all participate in the process of addressing them together as one united and peaceful people." 45

Similarly, the Christian Council of Ghana and the Ghana Catholic Bishops Conference joint meeting raised the issue of being religious leaders as their mandate in bringing faith perspectives to public issues. "Dearly Beloved citizens and men and women of goodwill resident in Ghana, we, the members of the Ghana Catholic Bishops' Conference and the Christian Council of Ghana, send you our warmest greetings of peace and love. We believe that the joy of the Risen Lord still remains with you and continue to fill you with hope. We have just concluded our May 2016 Annual Joint Meeting, held at St. Theresa Catholic Church, Kaneshie, Accra, during which we prayed and discussed issues of both Church and national importance. At the end of our meeting, we deem it appropriate as Christian religious leaders of our land to bring the following pertinent issues affecting our nation to the attention of our government and our citizens so we can all participate in the process of addressing them together as one united and peaceful people." 46

The prophetic role of the church further drives the issuance of communiques in Ghana. The Christian Council of Ghana indicates its basis for bringing Christian faith perspectives on public policy matters again as prophetic. 'We, the Heads of Churches/Organizations and Executive Committee members of the Christian Council of Ghana, having met on December 17, 2013, at the Secretariat of the Council, Accra; Having discussed issues pertaining to the socio-economic development of our dear nation; Acknowledging our prophetic role as development partners, which imposes a responsibility on us to continue to support nation building efforts and hold government accountable for the well-being of every citizen of this country.' ${ }^{47}$

The church leaders considered themselves as development partners. The thought of being development partners imposes a responsibility on them not only to support nation building efforts of the governments but also the total well-being of the ordinary citizens. The mandate of development partners brings them to the point of promoting national dialogue around the search for policies and strategies towards the economic growth, prosperity and peace of the people.

The communiques are done as a matter of concern. The Christian council of Ghana indicated in the communique that, "we are concerned that, the recent surge in unemployment, depreciation of the cedi, accidents on our roads, corruption, pollution of water bodies and labor unrest are very worrying and detrimental to the livelihoods of our people; That, the partisan manner in which we deal with national issues is not helping our

${ }_{44}$ Joint communique of the Christian Council of Ghana and the Ghana Pentecostal and Charismatic Council, issued at Accra on June 8, 2016.

45 Communique on National Issues by the Christian Council of Ghana adopted at the Joint Heads of Churches and Organizations and Executive Meeting of the Christian Council of Ghana held at its Secretariat on December 17, 2013.

46 Joint Press Statement by the Christian Council of Ghana and the Ghana Catholic Bishops' Conference Issued in Accra on May $18,2016$.

47 Communique on National Issues by the Christian Council of Ghana adopted at the Joint Heads of Churches and Organizations and Executive Meeting of the Christian Council of Ghana held at its Secretariat on December 17, 2013. 
development efforts.' 48

The church's commitment to matters of public issues is further derived from the fact of the sovereignty of God and his plan for a good end for all people. The communique of the Presbyterian Church of Ghana insists that on the sovereignty of God and the fact that the power of God directs the affairs of nations and peoples for good ends for his glory and the good of the people. ${ }^{49}$

\section{The Impact}

The communiques by the churches have received varied impacts. Like the prophets of old, there are instances that the perspectives of the churches have been received and considered positively in national public policy directions. The communiques sent to the PNDC to hand over the governance of Ghana to constitutional and democratic rule eventually received the expected response. The Ecumenical bodies were requested to submit representatives to the constituency assembly that finally drafted the constitution of the $4^{\text {th }}$ republic of Ghana.

On the other hand, there have been instances that the reactions and responses from governments and political party foot soldiers on Christian faith in the public space have been very unfriendly and negative. The Christian Council and the Catholic Bishops Conference pleaded with Kwame Nkrumah to grant freedom to all those who were detained in prison as a result of the application of the Preventive Detention Act. Again, the Christian Council of Ghana requested a meeting with the Prime Minister to discuss pertinent issues relating to human rights in Ghana. Nkrumah decided not to acknowledge the Christian Council of Ghana and the Catholic Bishops Conference. He did not eventually give them any attention when they raised their voices against the Preventive Detention Act.

The response of Nkrumah to the church leaders has been described by Gyampo as only barking without biting. ${ }^{50}$ The joint communique never influenced the Nkrumah regime, perhaps as a result of the fact that the regime was not fully democratic. Indeed, on the Christian Council of Ghana's request for a meeting with Nkrumah, the latter refused to meet the former citing his heavy pressure of public business as an excuse. ${ }^{51}$

Faith in public life has deepened the public relevance of the church. There is the public trust and confidence that the church as an institution of calm can be trusted to make interventions and intercessions whenever needed. Public theology ends up making significant contributions to the relevance of Christian theology. The fatherhood of God and other Christian concepts as 'you are the light of the world' become more relevant when church members encounter Christian witness in the public sphere.

\section{CONCLUSION}

Faith in public life can be associated with Christianity in Ghana from the days of the early Western missionaries. Christian faith perspectives on matters of public concerns however, assumed a wider scope with the practice of regular issuance of communiques to governments and the people of Ghana by the churches. Christian ministry is expected to be holistic. A holistic approach in Christian ministry is considered to lead to the holistic development of the nation for the common good and the glory of God. Church leaders subsequently, bring their faith perspectives to matters of public concerns as a ministerial mandate to be in pilgrimage with the people. The issuance of communiques, it has been observed, has given the churches even a bigger scope in their efforts to bring faith into public life.

To keep the theological balance of communiques, it has been noted that the church ought to avoid the tendency of making communiques becoming an extension of national and or international developmental goals. The construction of communiques must always be theologically and biblically informed even though the church must not be unaware of the existing developmental goals of the socio-political and cultural milieu within which it functions. The church must not at any time depart from its historical antecedents and Christian witness in its faith in the public sphere efforts.

\footnotetext{
${ }^{48}$ Communique on National Issues by the Christian Council of Ghana adopted at the Joint Heads of Churches and Organizations and Executive Meeting of the Christian Council of Ghana held at its Secretariat on December 17, 2013.

${ }^{49}$ Communique issued by the Presbyterian Church of Ghana (PCG) at the end of its $19^{\text {th }}$ General Assembly at Abetifi-Kwahu in the Eastern Region of Ghana from $16^{\text {th }}-22^{\text {nd }}$ August, 2019.

50 R.E. Gyampo, The Church and Ghana's Drive Towards Democratic Consolidation and Maturity. Journal of Political Science (2015): 161.

51 Anquandah. Agenda Extraordinaire: 80 years of the Christian Council of Ghana 1929-2009.
} 


\section{ABOUT AUTHOR}

Kwabena Opuni-Frimpong (PhD), Lecturer in African Christianity, Department of Religious Studies, Kwame Nkrumah University of Science and Technology, Kumasi - Ghana.

\section{BIBLIOGRAPHY}

Anquandah, James. Agenda Extraordinaire: 80 years of the Christian Council of Ghana 1929-2009. Accra: Asempa Publishers 2009.

Asante Emmanuel. Theology and Society in Context: A Theologist's Reflections on Selected Topics. Accra: Sonlife Press, 2014.

Communique on National issues by the Christian Council of Ghana adopted at the Joint Heads of Churches/ Organizations and Executive Committee Meeting of the Christian Council of Ghana held at its Secretariat on December 17, 2013.

Joint communique of the Christian Council of Ghana and the Ghana Pentecostal and Charismatic Council, issued in Accra on June 8, 2016.

Joint Press Statement by the Christian Council of Ghana and the Ghana Catholic Bishops' Conference Issued in Accra on May 18, 2016.

Communique issued by the All African Conference of Churches held at Desmond Tutu Conference Centre Nairobi, Kenya on November 29-30, 2016.

Communique issued by the Presbyterian Church of Ghana (PCG) at the end of its 19th General Assembly at Abetifi-Kwahu in the Eastern Region of Ghana from 16th - 22nd August, 2019.

Debrunner Hans W. A History of Christianity in Ghana. Accra: Waterville Publishing House 1967.

Essamuah Casely B. Genuinely Ghanaian. Trenton: Africa World Press 2010.

Gifford Paul. Ghana's New Christianity. Indianapolis: Indiana University Press 2004.

Gutierrez Gustavo. A Theology of Liberation. New York: Orbis Books 1988.

Gyampo, RE. The Church and Ghana's Drive Towards Democratic Consolidation and Maturity. Journal of Political Science (2015):161.

Aryee, Joseph R.A., An Anatomy of Public Policy Implementation, Avebury Brookfield USA 1997.

Aryee, Joseph R.A., Leadership and the Ghanaian State Today: Reflections and Perspectives. Accra: Checkpoint, 2017.

Karel T. August. The Quest for Being Public Church, The South African Challenge to the Moravian Church in Context 1737-2004. Bellville: The Print-Man 2009.

Kim, Sebastian. Theology in the Public Sphere: Public Theology as a Catalyst for Open Debate. London: SCM Press 2011

Kwamena-Poh M. A. Vision \& Achievement. Accra: Waterville Publishing House, 2011.

Kudajie JN and Aboagye -Mensah RK. Christian Social Ethics Accra: Asempa Publishers, 1992.

Mante, JOY and Aboagye-Dankwa D. Presbyterian Church of Ghana, Synod Decisions and the Rationale behind the decisions (1975-200), (Accra: Adwinsa Publications, 2014).

Smith Noel. The Presbytery Church of Ghana 1835-1960 Accra: Ghana Universities Press 1966.

Tveit Olav Fykse. The Role of Religion in Sustainable Development and Peace. Berlin World Council of Churches. February 17-18, 2016.

Opuni-Frimpong K. Christian Ministry of Advocacy. Accra: Sonlife Press 2015.

Presbyterian Church of Ghana Synod Decisions of $65^{\text {th }}$ Synod held at Sunyani on August 20-24, 1994.

Presbyterian Church of Ghana, Manual of Order. Accra: Waterville Publishing House, 2017.

Schweizer Peter A. Survivors on the Gold Coast. Accra: Smartline Publishing 2000.

Stott John. Issues Facing Christianity Today. London: Marshall Pickering 2006. 